\title{
Nilai-Nilai Pendidikan Karakter Pada Tema Pahlawanku Kelas 4 SD Dalam Buku Tematik Terpadu Kurikulum 2013
}

\author{
Meri Yuliani \\ Institut Pendidikan Nusantara Global \\ Meriyuliani994@gmail.com
}

\begin{abstract}
Abstrak. Tujuan penelitian ini adalah untuk mengetahui: (1) nilai- nilai pendidikan karakter yang ada dalam tema pahlawanku kelas VI SD dalam buku tematik kurikulum 2013. (2) pengintegrasian nilai-nilai pendidikan karakter pada siswa SD kelas VI pada tema pahlawanku dalam buku tematik kurikulum 2013. Penelitian ini menggunakan metode penelitian kualitatif dengan menggunakan pendekatan analisis isi, objek yang diteliti adalah pada buku tematik kurikulum 2013 dengan tema pahlawanku. Teknik pengumpulan data dengan menggunakan metode simak dan catat. Teknik analisis data menggunakan analisis isi (content analysis) yang digunakan untuk menelaah isi dari suatu dokumen. Hasil penelitian menunju kkan bahwa: (1) Nilai-nilai pendidikan karakter yang ada pada tema pahlawanku dalam buku tematik kurikulum 2013 antara lain, nilai karakter religius, nilai karakter Kerja keras, nilai karakter cinta tanah air, nilai karakter Cinta damai, nilai karakter jujur, nilai karakter semangat kebangsaan, nilai karakter tanggung jawab. (2) Pengintegrasian nilai - nilai pendidikan karakter pada tema pahlawanku dalam buku tematik kurikulum 2013 dengan melalui kegiatan (1) Pembiasaan, (2) Intrakurikuler, (3) melalui kegiatan peringatan hari besar kebangsaan dan, (4) ekastrakurikuler.
\end{abstract}

\section{Kata Kunci: Pendidikan Karakter, tema pahlawanku}

Abstract. The Purpose Of This researchis to fine out: (1) the character education values that exist in my hero theme grade VI in elementary school in the 2013 curriculum thematic book. (2) integrating the values of character students on my hero theme in the 2013 thematic integrated curriculum book. This study used a qualitative reserch method using content analysis, the object of study was the 2013 thematic integrated curriculum thematic book with my hero theme. Data collection tecniques using the data refer to the method and note. Data Analisys tecniques use content analysis which is used to examine the contents of a document. The result show that: (1) the character education values that exist on my hero theme in the 2013 curicculum thematic book, among others, religius character value,hard work character values, the value of the love character of the motherland, peace character values, honest character values, national spirit character values, character responsibility values, (2) integrating the values of character education on my hero theme in the 2013 curriculum thematic book through activities (1) habituation, (2) intracuricular (3) National Day Commemoration Activities, (4) Extracurricular.

Keywords: Character Building, My Hero Theme

\section{PENDAHULUAN}

Fenomena yang terjadi sekarang ini menunjukkan adanya gejaga degradasi moral yang sangat menghawatirkan khususnya pada generasi muda bangsa ini. Tolong menolong dan dan kejujuran sudah jarang sekali ditemukan dan tertutup oleh penipuan, penindasan, saling acuh tak acuh, mengambil hak orang lain, seks bebasdan masih banyak tindakan - tindakan kriminal lainnya.
Dunia pendidikan kini sedang memasuki masa-masa yang pelik, para peserta didik sebagai penerus peradaban seharusnya bisa menunjukkan karakter yang baik sebagai implementasi nilai dari salah satu tujuan pendidikan itu sendiri. Pendidikan karakter dimkasudkan sekaligus sebagai pembentukan karakter. Pendidikan karakter itu sendiri merupakan sebuah proses pembelajaran untuk menanamkan nilai-nilai luhur, budi pekerti, 
jujur, yang berakar pada ajaran agama, adat istiadat, dan nilai-nilaikeindonesiaan dalam rangka mengembangkan kepribadian peserta didik supaya menjadi manusia yang bermartabat, menjadi warga negara yang berkarakter sesuai dengan nilai-nilai luhur dan perjuanagn para tokoh perjuangan bangsa indonesia. Dengan demikian, siswa siswa membutuhkan pendidikan karakter yang akan membentuk karakter positif.

Ada banyak cara dan bahan yang dapat di kreasikan untuk mendidik, memupuk dan mengembangkan, serta membentuk karakter peserta didik, salah satunya adalah dengan melalui mata pelajaran yang sudah ada dalam kurikulum termasuk mata pelajaran ips.

Pendidikan karakter dalam materi ajar dapat disajikan melalui tokoh-tokoh perjuangan bangsa indonesia yang ada dalam materi ips SD kelas 4 yaitu tema pahlawanku., merupakan tokoh-tokoh perjuangan yang memiliki berbagai watak dan dan budi pekerti yang baik yang bisa diambil dan diterapkan kepada peserta didik.

Berdasarkan uraian diatas menarik untuk dilakukan penelitian dengan judul:" nilai- nilai karakter pada tema pahlawanku melalui tema pahlawanku Kelas $4 \mathrm{Sd}$ Dalam Buku Tematik Terpadu Kurikulum 2013 “ tujuan utama penelitian ini adalah (1) menganalisis nilai-nilai pendidikan karakter yang terkandung pada tema pahlawanku kelas VI SD dalam buku tematik terpadu kurikulum 2013, dan (2) pengintegrasian nilai- nilai pendidikan karakter pada tema pahlawanku dalam buku tematik terpadu kurikulum 2013 pada siswa SD kelas VI.

\section{METODE PENELITIAN}

Penelitian ini adalah penelitian
deskriptif kualitatif. Margono (2003), menyatakan bahwa penelitian deskriptif kualitatif merupakan penelitian yang memberikan informasi secara sistematis dan cermat tentang fakta-fakta aktual dan sifat populasi tetentu. Data dalam penelitian ini adalah ata sekunder yang diperoleh melalui buku ajar siswa kelas 4 SD dengan tema pahlawanku terbitan.

Sedangkanteknik pengumpulan data yang digunakan dalam penelitian ini adalah tehnik menyimak dan mendongeng. Validitas data dengan menggunakan triangulasi data dengan memeriksa kebenaran data terlebih dahulu dengan menggunakan perbandingan data dengan suber data yang satu dengan yang lainnya sehingga kebenaran akan data tersebut diuji dengan data yang berbeda.

Teknik analisis data yang digunakan adalah Content Analysis (Kajian isi). Analisis isi adalah teknik penelitian untuk refrensirefrensi yang dapat ditiru. Dan kesahihan data dengan memperhatikan konteksnya. Analisis isi berhubungan dengan komunikasiatau isi komunikasi (Bungin, 2003: 172)

\section{HASIL DAN PEMBAHASAN}

1. Nilai-nilai pendidikan karakter yang ada dalam tema pahlawanku pada buku tematik terpadu kurikulum 2013

Dea wasa ini berbgai pihak trutama dilingkugan pendidikan menuntut peningkatan kualitas karakter pada lembagalembaga pendidikan formal. Pendidikan karakter kini memang menjadi isu utama dalam pendidikan, selain menjadi bagian dari proses pembentukan ahlak peserta didik, pendidikan karakter ini pun diharapkan mampu menjai fondasi utama dalam mensukseskan generasi indonesia Emas 2025.

Berdasarkan hasil kajian dan interpretasi terhadap tema pahlawan pada buku tematik kurikulum 2013 ditemukan beberapa nilai pendidikan karakter yang berhubungan dengan 18 nilai karakter bangsa yang menjadi target sekaligus indikator keberhasilan pendidikan bangsa:

1. nilai karakter Religius

2. nilai karakter Kerja keras

3. nill karakter Cinta tanah air

4. nilai karakter Cinta damai

5. nilai karakter jujur

6. pendidikan karaktersemangat kebangsaan

7. Nilai pendidikan karakter tanggung jawab

Religius sebagai salah satu nilai karakter sebagai sikap dan prilaku yang patuh dalam melaksanakan ajaran agama yang dianut, toleran terhadap pelaksanaan ibadah lain, dan hidup rukun dengan pemeluk agama lain.

Nilai pendidikan karakter kerja keras terdiri atas sikap dan prilaku pantang menyerah, besyungguh-sungguh untuk mencapai kesuksesan tanpa mengenal lelah 
atau berhenti sebelum target kerja tercapai dan selalu mengutamakan dan memperhatikan kepuasan hasil pada setiap kegiatan yang dilakukan.

Cinta tanah air adalah perasaan yang timbul dari dalam hati seseorang warga negara untuk mengabdi, memelihara, membela, melindungi tanah airnya dari segala macam bentuk ancaman dan gangguan.

Cinta damai adalah cinta yang mengedepankan perdamaian dalam berinteraksi terhadap sesama umay manusia. Cinta damai yaitu orang yang bisa menghargai perbedaan yang dimiliki individu atau kelompok lain daripada dirinya atau kelompoknya sendiri. Menghargai dalam artian seseorang tidak asal menjude atau menghina perbedaan yang ada pada orang lain apalagi sampai melakukan kekerasan terhadap orang lain. Manusia tidak perlu menjadi orang yang ramah tamah, suka memuji, maupun menyapa tetapi manusia harus menjaga perbuatannya baik perkataan maupun perbuatan dari kekerasan yang merugikan orang lain.

Kejujuran adalah salah satu karakter bangsa indonesia, kejujuran termasuk dalam nilai moral. Prilaku jujur adalah dasar dari segala prilaku terpuji lainnya. Karakter jujur ini penting dan harusdimiliki oleh semua generasimuda indonesia agar kedepan tercipta generasi-generasi seperti para pahlawan kita terdahulu. Untuk mewujudkan pendidikan karakter anak bangsa yang menjadi pemimpin maka dari itu sangat penting prilaku juju ini menjadi dasar karakter yang harus dibudayakandan didukung untuk settiap generasi bangsa baru diindonesia.

Semangat kebangsaan adalah suatu keadaan yang menunjukkan adanya kesadaran untuk menyerahkan kesetiaan tertinggi dari setiap pribadi terhadap Negara atau Bangsa. Pengertian ini sejalan dengan makna semangat kebangsaan yang identik dengan konsep nasionalisme dan patriotisme. Nasionalisme adalah suatu paham yang menganggap bahwa kesetiaan tertinggi atas setiap pribadi wajib diserahkan kepada negara kebangsaan. Sedangkan patriotisme berarti semangat cinta tanah air atau sikap seseorang yang bersedia mengorbankan segala-galanya untuk mempertahankan bangsanya.

Karakter tanggung jawab adalah kesadaran manusia akan tingkah laku atau perbuatan yang disengaja maupun tidak disengaja. Tanggung jawab adalah ciri manusia beradab (berbudaya). Manusia merasa bertanggung jawab karena ia menyadari akibat baik atau buruk perbuatannya dan menyadari pula bahwa pihak lain memerlukan pengabdian atau pengorbanannya. Tanggung jawab dapat dibedakan menurut keadaan manusia atau hubungan yang dibuatnya, yaitu terhadap masyarakat, tanggung jawab terhadap bangsa dan negara dan tanggung jawab kepada Tuan Yang Maha Esa.

2. Implementasi Pendidikan Karakter Di Sekolah Dasar dengan tema pahlawanku pada buku tematik terpadu kurikulum 2013.

Membangun karakter bangsa menjadi tanggung jawab bersama semua pihak dan komponen dari bangsa ini untuk ikut terlibat membangun karakter yang kuat dan khas semua potensi bangsa harus bangkit dan bersatu untuk melakukan sebuah gerakan tindakan dalam membangun karakter bangsa agar negeri ini bangkit dan meraih cita-cita besarnya sehingga mampu sejajar dengan bangsa-bangsa besar laiin didunia bahkan mampu menjadi pusat peradaban.

Adapun bentuk-bentuk impelementasi pendidikan karakter pada tema pahlawanku adalah kepada siswa sekolah dasar adalah:

a) Melalui Kegiatan pembiasaan sehingga akan memperoleh siswa yang memiliki karakter dasar positif, adapun cara yang di tempuh guru misalnya Guru membiasakan mentauladani tokoh-tokoh yang memiliki jasa dalam kebangkitan negara indonesia.

b) Melalui kegiatan intrakurikuler misalnya dengan mengikuti upacara setiap hari senin untuk memberikan penghargaan kepada pahlawan terdahulu, dan mengikuti kegiatan IMTAQ yang dilaksanakan satu kali semingu dan dan mengikuti sholaat berjemaah untuk membentuk karakter religius peserta didik. 
c) Melalui kegiatan peringatan hari kebangsaan misalnya memperigati hari pahlawan sehingga akan membentuk karakter peserta didik semangat kebangsaan, cinta tanah air, menghargai, dan peduli

d) Melalui kegiatan ekstrakurikuler, materi kepahlawanan yang akan diintegrasikan ke dalam ekstrakurikuler mencakup aspek kesadaran berbangsa dan bernegara, kecintaan terhadap para pahlawan yang telah gugur, kecintaan terhadap tanah air. Implementasi tersebut akan diperkaya dengan nilai-nilai kecerdasan emosional, spiritual, serta khasanah budaya dan kearifan lokal. Berdasarkan hal tersebut, maka penerapan materi kepahlawanan untuk menanamkan karakter terhadap peserta didik melalui kegiatan ekstrakurikuler dapat mengembangkan bakat peserta didik. Penanaman nilai-nilai karakter melaluik kegiatan ekstrakurikuler lebih difokuskan kepada ekstrakurikuler yang dianggap relevan seperti kegiatan pramuka, dan pasukan pengibar bendera.

Terlaksannaya integrasi pendidikan karakter tidak lepas dari peran guru yang selalu menyelipkan nilai-nilai karakter yang ada pada tema pahlawan, dan adanya dukungan orang tua yang ikut aktif dlam mengawasi anaknya sehingga terciptanya pengamalan nilai karakter baik di sekolah maupun di rumah.

Penelitian ini didukung oleh Murniyetti (2016) yang mendapati bahwa terdapat tujuh cara yang dapat dilakukan guru untuk menanamkan nilai-nilai karakter terhadap peserta didik, di antaranya adalah (1) melalui aturan-aturan sekolah (disiplin, peduli lingkungan, tanggung jawab) (2) perlombaan sains antar peserta didik (kreatif, gemar membaca, rasa ingin tahu) (3) ajang penghargaan peserta didik berprestasi, (4) peringatan hari kebangsaan (5) praktik ibadah dan bimbingan kerohanian (6) kegiatan pramuka, (7) adanya akelas talenta.

Merujuk kepada hasil penelitian yang peulis lakukan serta didukung oleh beberapa penelitian terdahulu maka telah nampak secara jelas bahwa penanaman nilai-nilai pendidikan karakter dapat dilakukan dengan berbagai cara, berdasarkan hasil penelitian ini salah satu cara yang dilakukan adalah melalui tema pahlawanku pada buku tematik terpadu kurikulum 2013 kelas VI SD.

\section{KESIMPULAN:}

Berdasarkan hasil analisis diatas, maka apat disimpulkan hal-hal sebagai berikut:

1. Nilai-nilai pendidikan karakter yang terdapat pada buku tematik kurikulum 2013 dengan tema pahawanku antara lain, nilai karakter religius, nilai karakter cinta tanah air, nilai karakter kerja keras, nilai karakter cinta damai, semangat kebangsaan, disiplin dan tanggung jawab.

2. Menanamkan nilai-nilai pendidikan karakter pada peserta ddik dapat dilakyukan dengan pembiasaapembiasaan melalui kegiatan dikelas yang dilakukan secara terusmenerusdan konsisten setiap saat, sehingga peserta didik akan terbiasa melakukan hal-hal yang baik dan benar-benar tertanamdalam diri masing-masing peserta didik.

Saran:

1. Berdasarkan hasil penelitian disarankan bagi kepala sekolah bekerja sama untuk lebih mengimplementasikan nilai-nilai karakter di sekolah,

2. Guru harus memasukkan target-target karakter dalam setiap mata pelajaran sehingga dalam proses pembelajaran guru tidak hanya fokus pada materi-materi yang bersifat kognitif, akan tetapi bagaimana nilai-nilai karakter yang harus ditanamkan pada siswa sekolah dasar.

3. Dalam pengimplementasian pendidikan karakter di sekolah dasar bterdapat hambatan yakni kurangnya pengetahuan moral siswa, melihat latar belakang siswa yang kurang mendapatkan perhatian orang tua, dengan demikian pengetahuan moral siswa sangat minim, membuat tingkah lakusiswa cenderung cuek dengan prilaku baik yang dibiasakan dalam sekolah.

4. Bagi peneliti lain, hasil penelitian ini dapat dimanfaatkan sebagi rujukan penelitian lanjutan. 


\section{DAFTAR PUSTAKA}

Aji bagus priyambodo (2017) implementasi pendidikan karakter semangat kebangsaan dan cinta tanah air pada sekolah berlatar belakang islam dikota pasuruan. Jurnal sains psikologi, jilid 6, nomor 1, hlm 9-15

Bungin, Burhan. 2003. Content Analysis dan fokus and Grouf Discussion dalam penelitian sosial, jakarta: raja Grafindo Persada

Farida Iswayungtyas, (2012) Nilai-nilai pendidikan karakter pada materi ajar bahasa indonesia kelas 2 sd terbitan tiga serangkai.

Meri Yuliani, (2019) Monumen Perang Jagaraga Di Desa Jagaraga Sebagai Sumber Belajar Ips Di Smp Negeri 1 Sawan Kecamatan Sawan Kabupaten Buleleng. Jurnal pendidikan ips.

Moleong, Lexy J, 2007. Metode Penelitian Kualitatif, Bandung: Remaja Rosda Karya

Muta'alin, (2017) penanaman nilai-nilai pendidikan karakter pada pembelajaran ips di mts ngemplak boyolali. PhD Thesis. Univeristas Surakarta.

Nur Hidayah (2016) implementasi pendidikan karakter melalui pembiasaan di pondok psantren pabelan. Jurnal pendidikan sekolah dasar, vol 2, no. 1 